\title{
Blood Profile and Reflex Righting in Central Pain Induced Rats after Administration of Sernai Leaf Extract (Wedelia biflora)
}

\author{
Rinidar Rinidar ${ }^{*}$, Muhammad $\mathrm{Isa}^{2}$, Muhammad $\operatorname{Hasan}^{3}$ Teuku Armansyah ${ }^{1}$, Rumi S. Zamzami ${ }^{3}$, and Siti R. Ayuti ${ }^{2}$. \\ ${ }^{1}$ Pharmacology Laboratory of Faculty of Veterinary Medicine, Universitas Syiah Kuala, Banda Aceh, Indonesia \\ ${ }^{2}$ Biochemistry Laboratory of Faculty of Veterinary Medicine, Universitas Syiah Kuala, Banda Aceh, Indonesia \\ ${ }^{3}$ Clinical Laboratory of Faculty of Veterinary Medicine, Universitas Syiah Kuala, Banda Aceh, Indonesia
}

\begin{abstract}
Pain is a symptom of infection in the body but becomes crucial if it is not treated properly. Pain medication could be managed by administering anti-pain medications (analgesics). Currently, not all commercially available analgesic drugs can be used in animals, due to biochemical and metabolic variations between species causing difficulties in dosage determination and drug administration to the patient. This condition affects the drug efficacy which is incompatible with clinical relevance, has a narrow therapeutic index (NTS), and toxic. Wedelia biflora plants contain triterpenoid compounds that have received considerable attention from paramedics and pharmaceuticals, due to its ability as a therapeutic agent for chemopreventive, analgesic-antipyretic, anti-inflammatory and cancer. The purpose of this study was to obtain the basic ingredients of analgesic drugs. The 60 rats aged 3 months with bodyweight ranged 150-200 $\mathrm{g}$ were used in this study and divided into 2 experiments. In the first experiment, 30 rats were divided into 5 groups : $\mathrm{K} 1$ (control group) were given aquadest, the $\mathrm{K} 2$ was given $0.5 \mathrm{mg} / \mathrm{ml}$ meloxicam drug, the groups $\mathrm{K} 3$, K4, and K5 were given Wedelia biflora leaf extract with dose of $40 \mathrm{mg} / \mathrm{kg} \mathrm{BW}, 50 \mathrm{mg} / \mathrm{kg} \mathrm{BW}$, and 60 $\mathrm{mg} / \mathrm{kg} \mathrm{BW}$, respectively. The observation was carried out on pain response and blood profile of the rats. In the second experiment, the reflex righting of the rats in 5 group treatments were observed after administered with Wedelia biflora leaves extract at dose of 40,50,60,120, and $240 \mathrm{mg} / \mathrm{kg} \mathrm{BW}$, respectively. Central pain test was carried out using tail emersion method and hot plate, while righting reflexes were observed starting from, 30, 60, 120, 240 and 360 minutes after giving sernai leaf extract. The results showed that the Wedelia biflora leaves have the ability as analgesic in the rat without altering the blood profile, and also poses a positive effect on reflex righting.
\end{abstract}

Keywords: Wedelia biflora, analgesic, reflect righting.

\section{Introduction}

Wedelia biflora is an aggressive weed which forms a dense ground cover widespread as an invasive species on the Pacific Islands, Hong Kong, South Africa, Australia, Indonesia, and Srilanka. Empirically, Wedelia biflora has been known to have medicinal properties and to date has been studied scientifically itsantiplasmodial activity both invitro and invivo [1,2], anti allergic [3], and antipyretic and analgesic[4].

Several positive effects of Wedelia biflora have proven such as reducing the body temperature during fever, as a medicine for itching, treating wounds, and ulcers[5], as an antifungal, antimicrobial [6]. The leaves of Wedelia biflora are useful as a diuretic drug, while the flowers are useful for skin diseases overcome the Plasmodium falciparum infection [7,8], act as an antipyretic due Plasmodium berghei infection[9]. Wedelia biflora was also able to protect the liver function due to infection of Plasmodium berghei [10]. The active compound of Wedelia biflora have also been identified, such as the leaves contain triterpenoids [11]. Wedelia biflora extract contains several active compounds such as alkaloids, coumarin, flavonoids, steroids, terpenoids, tannins and saponins. Ethyl acetate extract of Wedelia biflora Ocontained terpenoids, alkaloids and tannins [12, 13].

The development of Wedelia biflora as a drug candidate is currently directed on its ability as an analgesic-antipyretic. This is based on the presence of triterpenoids which can act as analgesics. The development of analgesic drugs itself has important significance in the veterinary field. This is because analgesic-antipyretic in animals is not as easy and safe as in humans. The difficulties in animals treatment due to the large variations of animal species, it causing difficulties in determining the dose and administration of drugs which is suitable to the patient.

The analgesic-antipyretic group generally has a narrow therapeutic index (NTS) and included in Therapeutic Drug Monitoring and hypotension $[14,15]$. Therefore, a study of the development of analgesic and antipyretic drugs is necessary, especially for animals.

* Corresponding author rinidar@unsyiah.ac.id 


\section{Materials and Methods}

\subsection{Animals}

Healthy male rats (Rattus novergicus) weighing 150-200 gram were obtained from the Pharmacology Laboratory of Faculty of Veterinary Medicine, Universitas Syiah Kuala , Banda Aceh. The use of these experimental animals has been approved by the Ethics Committee of Faculty of Veterinary Medicine.

\subsection{Plant material}

Fresh simplisia Wedelia biflora leaves with $<5 \%$ water content was collected from Darussalam, Banda Aceh. The Simplisia was processed into powder form and then extracted using maceration method according to the Pharmacopeia IV, Indonesia.

\subsection{Experimental Design}

\subsubsection{Anti Pain and Blood Profile}

This research was designed using a Completely Randomized Design (CRD). Rats were randomly divided into 5 groups; K1 (control group) were given aquadest, the $\mathrm{K} 2$ was given $0.5 \mathrm{mg} / \mathrm{ml}$ meloxicam drug (SigmaAldrich), K3, K4, and K5 were given Wedelia biflora leaf (WBL) extract with dose of $40 \mathrm{mg} / \mathrm{kg} \mathrm{BW}, 50 \mathrm{mg} / \mathrm{kg} \mathrm{BW}$, and $60 \mathrm{mg} / \mathrm{kg} \mathrm{BW}$, respectively, for 3 consecutive days. Rats were given thermal stimulation using the tail immersion test method. The reaction time was measured after 15, 30, 60, 90, and 120 minutes (M1, M2, M3, M4, and M5). Blood collection was carried out on day 3 and the effect of treatment on erythrocytes, leukocytes, and hemoglobin values were observed.

\subsubsection{Righting refleks}

Rats were randomly divided into 5 treatment groups and given graded doses of Wedelia biflora extract at graded level of $(40,50,60,120$, and $240 \mathrm{mg} / \mathrm{kg} \mathrm{BW}$, respectively). Reflex righting in mice was observed at 30 , $60,120,240$, and 360 minutes after extract administration . Development of body weight of mice was measured 3 times for 1 week. The amount of reflex righting loss and death was counted for 24 hours, while for live animals were observed for 14 days.

\subsubsection{Research Maps}

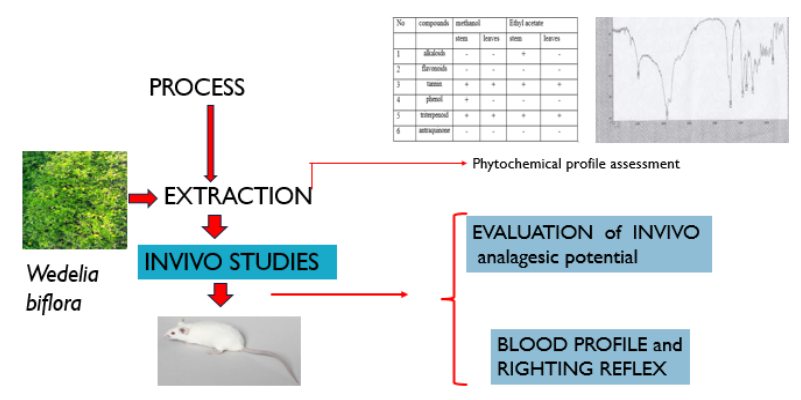

\section{Results and Discussion}

\subsection{Pain Response}

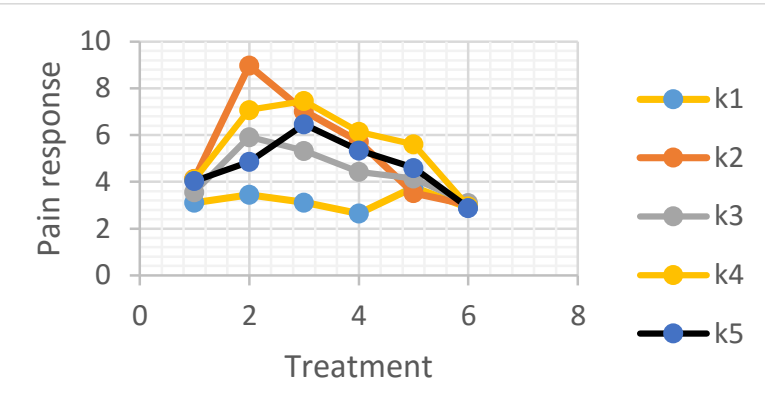

Figure 1. Overview Pain response in rats after administration of Wedelia biflora extract.

Note : K1: negative control, K2: positive control, K3, K4, and K5: Treatmentwith dose of 40,50 and $60 \mathrm{mg} / \mathrm{kg}$, respectively

The pain response to the administration of $\mathrm{k} 2, \mathrm{k} 3$, $\mathrm{k} 4$, and $\mathrm{k} 5$ starts its action as pain relief in thermalinduced mice at the $30^{\text {th }}$ minute. In $\mathrm{K} 2$ and $\mathrm{K} 3$ groups, the drug reaction decreased slowly, meanwhilein $\mathrm{K} 4$ and $\mathrm{K} 5$ groups, the anti-pain reaction was still present up to 60 minutes then gradually decreased and stopped at the $120^{\text {th }}$ minute. In the control group (K1), there was no pain effect was observed because only aquadest was given. The blood test results are displayed in the Table 1 ..

Table 1. The effect of Wedelia biflora extract on blood profile in Rats

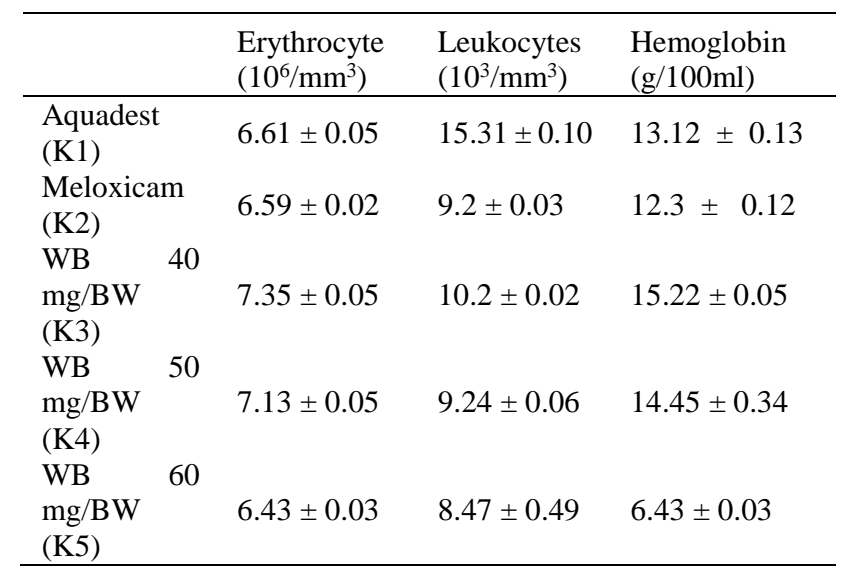

Evaluation of the number of leukocytes, erythrocytes, and hemoglobin concentrations is very important in determining the effect of the active ingredient in Wedelia biflora leaf extracts to the hematopoietic system.

\subsection{Blood Profile}

The number of erythrocytes increased in rats that was administrated with Wedelia biflora leaf extract at dose of $40 \mathrm{mg} / \mathrm{kg} \mathrm{BW}$ (K3) and $50 \mathrm{mg} / \mathrm{kg} \mathrm{BW}$ (K4) compared to control (K1), meloxicam (K2), and leaf extracts of Wedelia biflora at dose of $60 \mathrm{mg} / \mathrm{kg}$ bb (K5). The antipain medication in $\mathrm{K} 2$ and $\mathrm{K} 5$ did not increase the number of erythrocyte cells as compared to the control (K1). 
These results showed that the administration the extract at dose of $40 \mathrm{mg} / \mathrm{kg} \mathrm{BW}(\mathrm{K} 3)$ and $50 \mathrm{mg} / \mathrm{kg} \mathrm{BW}(\mathrm{K} 4)$ poses a good effect on erythrocyte cells. It is known that erythrocytes play a role in maintaining the immune system, hemoglobin releases free radicals that function to kill the pathogen cell membranes. When the number of leukocytes increase, it gives an indicator of the possibility of inflammation. This can be seen in the K1 (control) group that was only given aquadest, it showed high leukocyte levels of $15.31 \mathrm{x} 103 / \mathrm{mm} 3$. The normal leukocyte level limit in rats is $5.0-13 \times 103 / \mathrm{mm}^{3}$. In K1, rats experienced inflammation at low levels. An increase in leukocyte count was assumed due to stimulation of lymphopoiesis and/or increased lymphocyte release from lymph myeloid tissue. In this study, the administration of meloxicam and Wedelia biflora leaf extract was able to reduce inflammation and reduce the number of leukocytes under normal circumstances.

The hemoglobin $(\mathrm{Hb})$ values in $\mathrm{K} 3$ and $\mathrm{K} 4$ from the treatment were higher than the control (K1), K2 and K5 groups treatments. However, the best $\mathrm{Hb}$ levels were observed in the K5 group with $\mathrm{Hb}$ value of $15.22 \mathrm{~g} / 100$ ml. Normal Hb levels rats are 15-16 g / $100 \mathrm{ml}$ (16).

In this research, it was seen that the administration of Wedelia biflora leaf extract had a positive effect on erythrocytes, leukocytes, and hemoglobin with best values was observed in $\mathrm{K} 4$ with dose of $50 \mathrm{mg} / \mathrm{kg} \mathrm{BW}$. The K4 group also possed the best anti-pain ability in in which the pain rises slowly and decreases slowly, did not interfere with the number of erythrocytes, and able to suppress inflammation by stabilizing leukocytes and hemoglobin in normal levels. Hemoglobin has an important role in forming erythrocytes, binding oxygen to $\mathrm{HBO}_{2}$, transporting it to the lungs and the whole body, and returning $\mathrm{CO}_{2}$ to the lungs for releasing through exhale.

\subsection{Righting Reflex Performance}

The results of reflex righting in rat induced by thermal pain are shown in Figure 2.

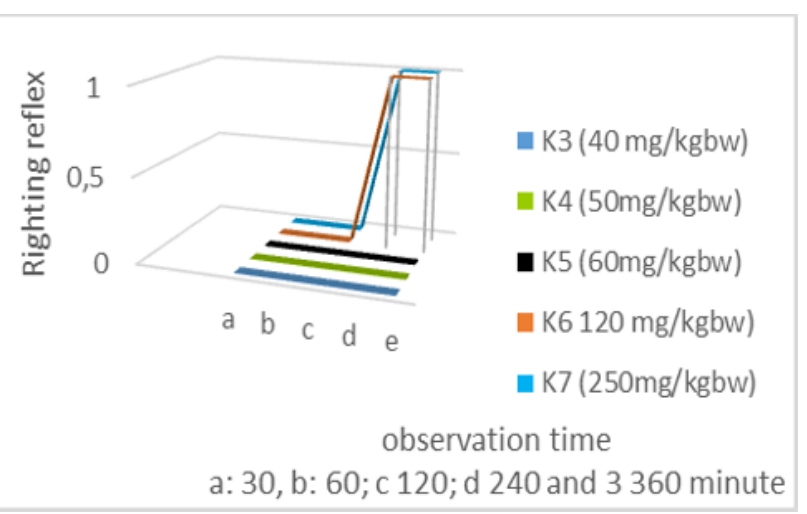

Figure 2. The reflex righting response in rats induced with Wedelia biflora extract.

The observations showed that rats fed with the extract of Wedelia biflora leaves were able to improve their position very well within 30 seconds, but at increased doses to 120 and $240 \mathrm{mg} / \mathrm{kg} \mathrm{BW}$ returned to the nominal position at 240 and 360 minutes.
Observing the reflex righting in rats given Wedelia biflora leaf extract was very important. Rats were observed whether they were able to return to the normal position which were measured by time. If the rat does not quickly return to its normal position with footprints on the floor, its indicated the disturbances in the rat vestibular system due to the active compound content in the extract. In this study, the rats were able to to turn back to normal position within 30 seconds after given the extract at dose of $40 \mathrm{mg} / \mathrm{kg} \mathrm{BW}, 50 \mathrm{mg} / \mathrm{kg} \mathrm{BW}$, and $60 \mathrm{mg} / \mathrm{kg} \mathrm{BW}$, whereas at higher dose (up to $240 \mathrm{mg} / \mathrm{kg} \mathrm{BW}$ ), the time needed was about 360 minutes, and the rats was still in conscious stage

\section{Conclusion}

Wedelia biflora has a positive effect on blood profile at doses of $40 \mathrm{mg} / \mathrm{kg} \mathrm{BW}$ and $50 \mathrm{mg} / \mathrm{kg} \mathrm{BW}$ in rat and on improving reflex performance at doses of 40, 50, and 60 $\mathrm{mg} / \mathrm{kg} \mathrm{BW}$..

\section{Acknowledgments}

Thank you to the Directorate of Research and Community Service Directorate General of Research and Technology Strengthening Ministry of Research, Technology, and Higher Education through research grants for Universitas Syiah Kuala.

\section{References}

1. Ariesari RA: Potensi Ekstrak Daun Sernai (Wedelia biflora) Sebagai Antipiretik pada Mencit (Mus musculus). Skripsi. Fakultas Kedokteran Hewan, Universitas Syiah Kuala, Banda Aceh. 2015.

2. Isa M: Identifikasi kandungan senyawa kimia aktif Wedelia biflora dan uji bioaktivitasnya sebagai antiplasmodium bergei. J. Med. Vet. 2014; 8(1): 51-55

3. Rinidar, Isa M, Sugito: The potential of Sernai Leaf extract (Wedelia biflora) in response to the secretion of Type 1 and 2 T helper cell cytokines in mice exposed to Plasmodium berghei. Research Report. Faculty of Veterinary Medicine. Universitas Syiah Kuala, Banda Aceh. 2014.

4. Rinidar, Isa M, Sugito. The Effect of Wedelia biflora Leaves Extracts On The Inflammation Cause by Allergic Reactions of Dermatitis in Mice (Mus musculus). The Proceedings of 2 nd annual International Conference Unsyiah. 2014; 2(1): 434-436.

5. Rinidar, Isa, Armansyah, et al.: Pharmacological Testing of Analgesic and Antipyretic Effects of Sernai Leaf Water Extract (Wedelia biflora) on mice (Mus musculus). Research report. Veterinary Pharmacology Laboratory. Faculty of Veterinary Medicine. Universitas Syiah Kuala, Banda Aceh. 2014.

6. Heyne K: Indonesian Useful Plants. Volume III. Yasasan Sarana Wana Jaya, Ministry of Forestry of the Republic of Indonesia. Jakarta. 1987.

7. Hasballah K, Murniana, Al-Azhar: Antibacterial and antifungal activity of the Wedelia biflora plant. Jurnal Kedokteran Yarsi. 2006;4(1) : 038-045.

8. Isa M, Rinidar, Armansyah TR: Antiplasmodium activity of Sernai (Wedelia biflora) methanol extract 
on Plasmodium Falciparum in vitro. Research Report. Faculty of Veterinary Medicine. Universitas Syiah Kuala, Banda Aceh. 2007.

9. Rinidar, Isa M: The Inhibition Concentration (IC50) Rak of Methanolic Extract of Wedelia biflora on Plasmodium Falciparum Incuated for 32 and $\mathbf{7 2}$ Hours. Jurnal Medika Veterinaria. 2013; 7 (10).:.8-12

10. Isa M, Rinidar, Armansyah TR: Isolation and Identification in Active Compounds From Sernai Leaf (Wedelia biflora) As an Antiplasmodium in invivo Test. Research Report. Faculty of Veterinary Medicine. Universitas Syiah Kuala, Banda Aceh. 2008.

11. Isa M, Rinidar, Sugito: Antiplasmodium activity of sernai leaves (Wedelia biflora) and evaluation of kidney and liver function in mice infected with Plasmodium berghei. Jurnal Veteriner. 2011; 13(2) 167 $-175$

12. Isa M: Identify the content of the active chemical compound Wedelia biflora and test its bioactivity as an antiplasmodium bergei. J. Med. Vet. 2014; 8(1): 51-55.
13. Meena AK, Rao MM, Komalpreet K, et al. : Comparative evaluation of standardisation parameters between Wedelia genus species. Journal of Pharma Sciences and Research. 2010; 1(3): 207-210.

14. Rinidar, Isa M, Armansyah TR, et al. : Phytochemical test of ethnacetate extract of sernai leaf stems (Wedelia biflora). Research Report. Veterinary Pharmacology Laboratory. Faculty of Veterinary Medicine. Universitas Syiah Kuala. Banda Aceh. 2015.

15. Jones RS: Nonsteroidal anti-inflammatory drugs in the cat. Veterinary Anaesthesia and Analgesia. 2007; 34 225-227.

16. White S, Wong HY: Standards of laboratory practice:Analgesic drug monitoring. Clinical Chemistry. 1998; 44(5): 1110-1123.

17. Smith JB, Mangkoewidjoyo, S: Maintenance, breeding and use of experimental animals in the Tropics. Universitas Indonesia Press. 1988

18. Verhoeven MTW, Gerritzen MA, Hellebrekers LJ, et al.: Indicators used in livestock to assess unconsciousness after stunning: a review. Animal. 2015; 9(2): 320-30. 